Erratum

\title{
Erratum to "Meprin Metalloprotease Deficiency Associated with Higher Mortality Rates and More Severe Diabetic Kidney Injury in Mice with STZ-Induced Type 1 Diabetes"
}

\author{
John E. Bylander, ${ }^{1}$ Faihaa Ahmed, ${ }^{2}$ Sabena M. Conley, ${ }^{2}$ Jean-Marie Mwiza, ${ }^{2}$ \\ and Elimelda Moige ${ }^{2}{ }^{2}$ \\ ${ }^{1}$ Department of Environmental Sciences, Pennsylvania State University, Harrisburg, Middletown, PA 17057, USA \\ ${ }^{2}$ Department of Biology, North Carolina A\&T State University, Greensboro, NC 27411, USA \\ Correspondence should be addressed to Elimelda Moige; eongeri@ncat.edu \\ Received 3 June 2018; Accepted 7 June 2018; Published 5 July 2018
}

Copyright (c) 2018 John E. Bylander et al. This is an open access article distributed under the Creative Commons Attribution License, which permits unrestricted use, distribution, and reproduction in any medium, provided the original work is properly cited.

In the article titled "Meprin Metalloprotease Deficiency Associated with Higher Mortality Rates and More Severe Diabetic Kidney Injury in Mice with STZ-Induced Type 1 Diabetes" [1], the meprins in Figure 1(b) were mistakenly duplicated due to a production error. The figure has been corrected in place.

\section{References}

[1] J. E. Bylander, F. Ahmed, S. M. Conley, J.-M. Mwiza, and E. M. Ongeri, "Meprin metalloprotease deficiency associated with higher mortality rates and more severe diabetic kidney injury in mice with STZ-induced type 1 diabetes," Journal of Diabetes Research, vol. 2017, Article ID 9035038, 11 pages, 2017. 


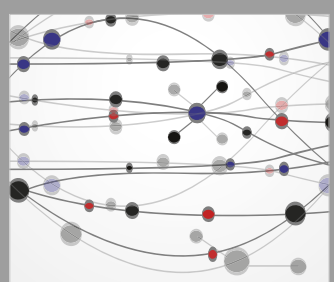

The Scientific World Journal
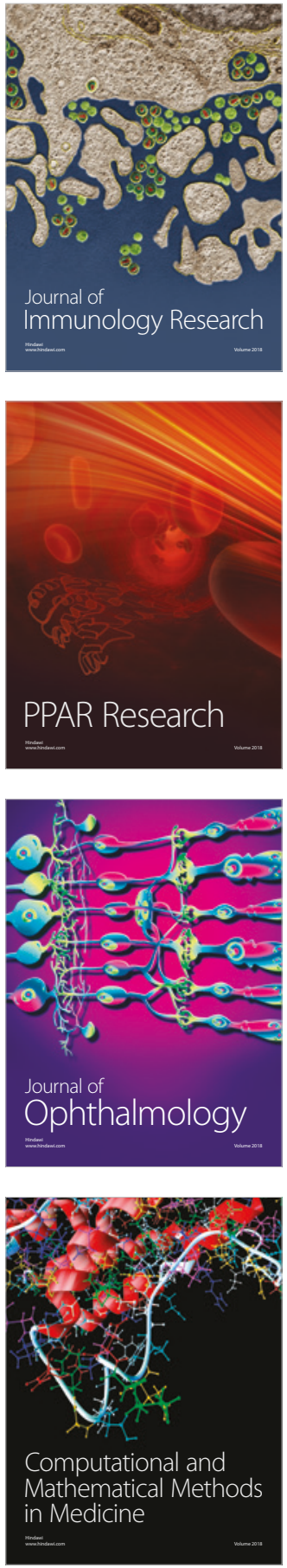

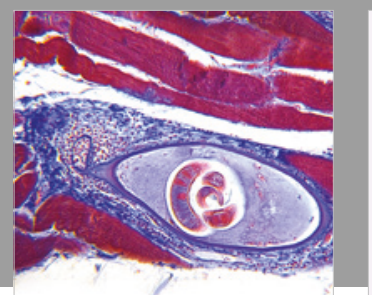

Gastroenterology Research and Practice

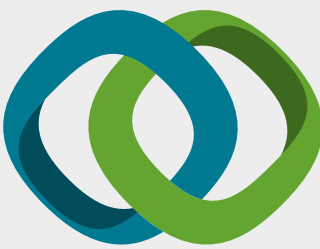

\section{Hindawi}

Submit your manuscripts at

www.hindawi.com
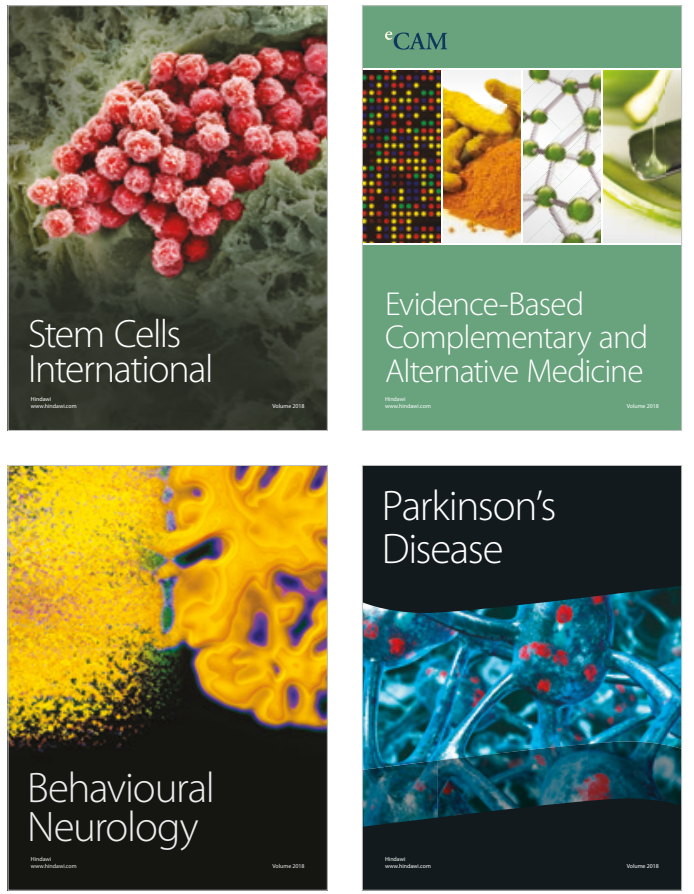

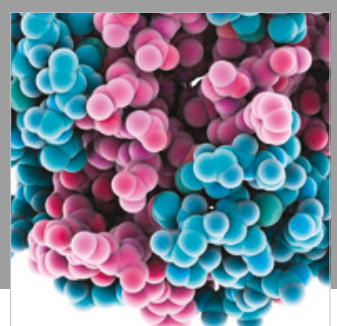

ournal of

Diabetes Research

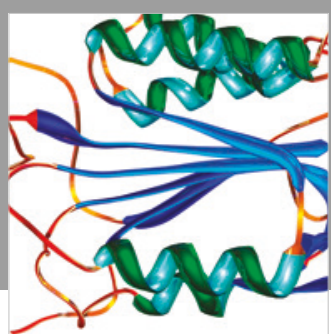

Disease Markers
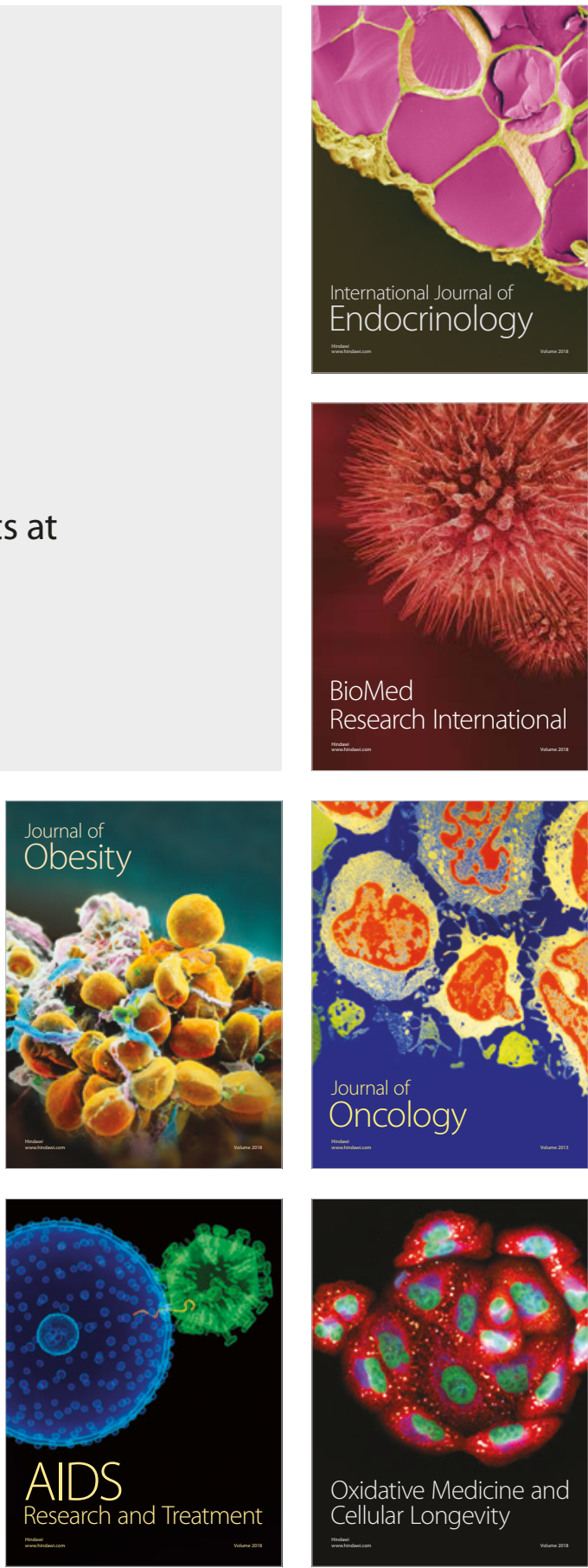